\title{
TRANSMISSION OF SOUND THROUGH BUILDING MATERIALS
}

\author{
By V. L. Chrisler
}

ABSTRACT

This paper contains a report of the work on sound transmission through (1) various stud partition walls covered with different wall boards, (2) a few masonry walls, and (3) a few compound walls. Attention is called to the fact that an equal degree of sound insulation can be obtained with lighter walls when they are made double or made with alternate layers of different material fastened together. The results are given for four frequency bands covering a range from 250 to 3,365 cycles per second. Specifications for the construction of the various panels used in transmission tests are appended.

\section{CONTENTS}

Page

IT. Discussion of results

III. General specifications for construction of test panels _. .

1. Erection of wood studs _.

2. Erection of brick wall

3. Erection of gypsum tile

4. Lime brown coat on masonry

5. Gypsum brown coat on masonry . 232

6. Smooth white finish coat

7. Erection of metal studs

8. Erection of solid partitions

9. Scratch coat, gypsum plaster, on lath

10. Brown coat, gypsum plaster, on lath

11. Erection of metal lath

12. Erection of gypsum wall board........ 234

13. Erection of asbestos board and Celotex .

IV. Description of panels._. 235

\section{INTRODUCTION}

In a previous paper ${ }^{1}$ the data on sound transmission were given for a large number of lath and plaster partition walls. Similar measurements have since been made on partition stud walls covered with gypsum wall board, Celotex, Flax-li-num, and asbestos hard millboard; also on a few types of masonry partition walls.

The method used was the same as that outlined in the previous paper.

1 Scientific Paper of the Bureau of Standards No. 526; also in American Architect, Nov. 5, 1925.

$49648^{\circ}-27$ 


\section{DISCUSSION OF RESULTS}

The masonry panels measured, consisting of 3-inch gypsum tile or block, 4-inch brick walls, and 4-inch hollow tile, previously reported, indicated a slightly greater transmission when plastered with lime than with gypsum plaster. This difference is probably due to the greater strength of the gypsum plaster which makes the wall somewhat stiffer, but the difference is not large enough to be of any practical importance.

Panels Nos. 55 to 58 are of interest in showing that a fairly soundproof wall can be built up of layers of different materials. Panel No. 58 (wood studs, Sheetrock, felt), for example, is a better sound insulator than panels Nos. 25 or 26 , which are 4 -inch brick walls. This shows very definitely that in walls which are not uniform in structure, weight is not, as has been claimed, ${ }^{2}$ the only factor to be considered in constructing a soundproof wall.

To form a clear idea as to how sound is transmitted through a wall it is necessary to consider how the air vibrations which constitute sound waves are transmitted through a partition wall from one room or space to another.

Sound waves in air consist of alternate compressions and rarefactions, and if there are no holes or cracks in the wall to provide an air path along which the waves can pass directly from one side to the other, the only mode of transmission is by setting the wall itself in vibration. The wall yields a very little to the pressure of each sound wave that strikes it, so that it is thrown into a corresponding state of vibration; and the vibrating wall in turn sets the air on the other side in motion, just as the diaphragm of a telephone receiver or of a loud speaker sets up sound waves which are then propagated through the air to the listener's ear.

A solid wall or a smaller panel, such as a wooden door, thus acts like a more or less elastic diaphragm held at the edges; and it is obvious that the less the wall moves back and forth in response to the sound waves falling on one side of it, the fainter will be the sound set up on the other side. Hence, making the wall stiffer or heavier, or both, makes it a better sound insulator.

The behavior of compound walls containing inclosed air spaces is not quite so simple. Between two adjacent studs, each face of such a wall consists of a flexible panel held more or less rigidly at its edges. The face toward the source of sound is thrown into vibration and this sets up corresponding sound waves in the dead air space. These throw the second face into vibration and so, finally, sound waves are set up in the air on the farther side of the wall. A simpler way to

2 Paul Sabine, Transmission of sound by masonry partitions, The Am. Architect, July 4, 1923; also Transmission and absorption of sound by wood stud partitions, The Am. Architect, Aug. 5, 1926. 
look at it is that the inclosed air acts like an elastic crosstie between the two surfaces of the wall, but this connection is so weak that the motion of the second surface is very much less than that of the first. The connection is very ineffective, the transmission is low, and the air space is a good insulator. This is illustrated by panels Nos. $30 \mathrm{~b}$ and $30 \mathrm{c}$, No. $30 \mathrm{~b}$ being a single panel and $30 \mathrm{c}$ a double panel. In the case of the double panel insulation has been increased considerably more than it would have been if a single panel of the same weight had been used. However, if a rigid cross connection is established in the middle of the double panel, the two parts are obliged to move together. In this way the first part is prevented from moving so much because of the increase in rigidity, but the second part moves very much more than without the connecting tie. The net result is that the transmission is increased. Thus while a single strut or crosstie does not constrain the whole wall, the insulating value of the air space is very much reduced.

Materials, such as sawdust, slag, or some of the heat insulators, are often introduced into this air space, as it has generally been claimed that these materials also improve the sound insulation. The effect of such a filler depends on circumstances. The filler may absorb svund, but it may also form a solid connection between the two surfaces, the connection being more or less soft or rigid according to the material. Moreover, the filler adds to the weight of the wall and this in itself tends to decrease the vibration of the wall as a whole and to improve the insulation.

The net result can not be predicted, but from the results obtained at the Bureau of Standards it appears that such a filling material is usually of doubtful value. Although it has been a common assumption with builders that good heat insulating materials are likewise good sound insulators, experiment does not bear this out in all cases This is best illustrated by referring to the results on panels Nos. 59a to $59 \mathrm{e}$. At the lower frequency bands the double panel No. 59a transmitted almost as much sound as the single panel No. 59. After hair-felt pads were placed above and below the wooden blocks supporting the corners of the second panel, No. 59b, leaving the air space the same as for No. 59a, the transmission was decreased considerably. Hair felt, single-ply Cabots Quilt, and Celotex were then introduced into this air space, panels Nos. $59 \mathrm{~d}$ and $59 \mathrm{e}$, respectively, without materially changing the transmission. These results indicate that practically all of the sound energy was transferred from the first surface to the second one through the corner supports, and that if filling material is introduced loosely into the air space in such a wall it has little, if any, value in improving the sound-insulating qualities of the wall. This agrees with the results found by Paul 
Sabine for hair felt. ${ }^{3} \mathrm{He}$ also found that heavier materials, such as sawdust and slag, increased the sound transmission. Similar experiments with stud walls at the Bureau of Standards, employing as a filler some of the heavier materials commonly used for heat insulation, have given a like result.

The numerical form in which the results are expressed in the present paper is the same as that employed in Bureau of Standards Scientific Paper No. 526. This form is employed for the purpose of expressing the results so that they correspond to the impression produced on the ear rather than to their effect on measuring instruments. There is an important difference between these two cases.

It is well recognized that as the energy of a sound wave increases the response of the ear fails to keep pace with it. We, therefore, have two kinds of intensity - that of the physical scale and that of the ear scale. These scales are connected by the following empirical relationship: The intensity of the sensation of loudness on the ear scale is proportional to the logarithm of the intensity of loudness on the physical scale.

The ratio of the intensity of the incident sound to that of the transmitted sound, both on the physical scale, is a measure of the insulation of the partition to sound, and is called the reduction factor. The logarithm of this ratio is a measure of the insulating property of the partition on the ear scale, and in this paper the transmission results are expressed in this manner. A panel with a reduction factor of $1,000,000$ transmits one-millionth of the incident sound energy, physically speaking, and its insulating value on the ear scale is 6 , because 6 is the logarithm of $1,000,000$. Similarly, a panel with a reduction factor of 1,000 transmits one-thousandth of the incident sound, and its insulating value on the ear scale is 3 , because 3 is the logarithm of 1,000. For example, if the intensity of the incident sound energy were 6 (on the ear scale) the intensity of the sound transmitted by the first panel would be reduced by the logarithm reduction factor, also 6 , reducing the intensity on the ear scale to 0 , the threshold of audibility; while that transmitted by the second panel would be reduced by the logarithmic reduction factor 3 , giving an intensity of 3 on the ear scale.

In this case there would be a decided difference to the ear between the two panels. If, however, the intensity of the incident energy were 9 , the intensity as heard through the first panel would be 3 and through the second panel 6 . In this case the sound as heard through the second panel would be twice as loud as that heard through the first panel..$^{4}$ As a third case, suppose the intensity of the incident energy to be 15 . The intensities as heard through the two panels

3 Paul Sabine, Architectural acoustics, The Armour Engineer, May, 1926.

4 New methods and apparatus for testing the acuity of hearing, Harvey Fletcher, September, 1925. Reprint B-151-1, Bell Telephone Laboratories. 
would be 9 and 12 . In this case the ear would still indicate that the first panel was the better insulator, but the sound would appear only one-third ouder through the second panel than through the first panel. The average person hearing this sound through the first panel and, after a short interval, hearing it through the second panel would probably say that there was very little $d$ fference between the two panels. The effectiveness of a panel with a given reduction factor as a sound insulator is, therefore, a relative matter, and it is not justifiable to say that one partition is two or three times as good as another, even though the reduction factors are two or three times as great, because the sound as heard by the ear is dependent upon the incident sound energy.

It should also be borne in mind that the usual wall openingsdoors and windows-insulate considerably less than any of the wall partitions tested. When such openings are present the partition wall with its better insulation plays but a minor part in the transmission of the sound.

TABLE 1.-Results: Sound transmission

\begin{tabular}{|c|c|c|c|c|c|c|c|c|c|}
\hline \multirow{2}{*}{ Panel No. } & \multicolumn{4}{|c|}{$\begin{array}{l}\text { Logarithm of reduction factor at } \\
\text { frequency bands- }\end{array}$} & \multirow[b]{2}{*}{ Panel No. } & \multicolumn{4}{|c|}{$\begin{array}{l}\text { Logarithm of reduction factor at } \\
\text { frequency bands- }\end{array}$} \\
\hline & $\begin{array}{l}250-251 \\
\mathrm{cy} \cdot / \mathrm{sec} .\end{array}$ & $\begin{array}{c}1,000- \\
1,065 \\
\mathrm{cy} . / \mathrm{sec} .\end{array}$ & $\begin{array}{c}2,000- \\
2,385 \\
\text { cy. } / \text { sec. }\end{array}$ & $\begin{array}{c}3,000- \\
3,365 \\
\mathrm{cy} \cdot / \mathrm{sec} .\end{array}$ & & $\begin{array}{l}250-251 \\
\mathrm{cy} \cdot / \mathrm{sec} .\end{array}$ & $\begin{array}{c}1,000- \\
1,065 \\
\mathrm{cy} . / \mathrm{sec} .\end{array}$ & $\begin{array}{c}2,000- \\
2,385 \\
\text { cy./sec. }\end{array}$ & $\begin{array}{c}3,000- \\
3,365 \\
\text { cy./sec. }\end{array}$ \\
\hline $\begin{array}{l}29 \\
30 \mathrm{a} . \ldots \\
30 \mathrm{~b} . . .\end{array}$ & $\begin{array}{l}4.31 \\
\text { 4. } 64 \\
3.58 \\
3.35 \\
4.31\end{array}$ & $\begin{array}{l}4.67 \\
4.88 \\
3.97 \\
3.74 \\
3.93\end{array}$ & $\begin{array}{l}5.45 \\
5.84 \\
4.22 \\
4.09 \\
4.21\end{array}$ & $\begin{array}{l}5.64 \\
6.13 \\
4.23 \\
4.42 \\
4.35\end{array}$ & $\begin{array}{l}56 \ldots \ldots \\
57 \ldots \\
58 . \ldots \\
59 \ldots \\
59 \mathrm{a} . .\end{array}$ & $\begin{array}{l}3.16 \\
3.48 \\
5.28 \\
3.41 \\
3.57\end{array}$ & $\begin{array}{l}3.60 \\
3.34 \\
5.34 \\
3.29 \\
5.00\end{array}$ & $\begin{array}{l}5.26 \\
3.51 \\
6.26 \\
4.42 \\
6.24\end{array}$ & $\begin{array}{l}6.14 \\
3.07 \\
6.00 \\
4.34 \\
6.82\end{array}$ \\
\hline $\begin{array}{l}30 \mathrm{c} \ldots \ldots \\
50 \ldots \ldots \\
51 \ldots \ldots \\
55 \\
55 \ldots . .\end{array}$ & $\begin{array}{l}5.26 \\
4.35 \\
3.58 \\
3.15 \\
2.31\end{array}$ & $\begin{array}{l}5.61 \\
4.64 \\
4.58 \\
2.54 \\
2.49\end{array}$ & $\begin{array}{l}6.53 \\
4.87 \\
5.21 \\
2.69 \\
2.96\end{array}$ & $\begin{array}{l}7.35 \\
3.97 \\
4.70 \\
2.56 \\
2.93\end{array}$ & $\begin{array}{l}59 \mathrm{~b} \\
59 \mathrm{c} \\
59 \mathrm{~d} \\
59 \mathrm{e}\end{array}$ & $\begin{array}{l}4.85 \\
4.90 \\
4.94 \\
5.41\end{array}$ & $\begin{array}{l}5.09 \\
5.13 \\
4.94 \\
5.46\end{array}$ & $\begin{array}{l}7.24 \\
7.15 \\
7.47 \\
7.56\end{array}$ & $\begin{array}{l}\text { 7. } 20 \\
6.90 \\
7.01 \\
\text { 7. } 19\end{array}$ \\
\hline
\end{tabular}

In addition to these results, sound transmission measurements were repeated on three panels previously reported in Scientific Paper No. 526, which were plastered with lime plaster, as it was thought that the transmission of the plaster might change due to the fact that chemical changes in lime plaster are probably not complete for at least a year after the plaster is applied. The panels had been allowed to age at least three months before the first measurements reported were made.

The transmission values expressed as logarithms of the reduction factor are:

\begin{tabular}{|c|c|c|c|c|c|c|c|c|}
\hline \multirow[b]{2}{*}{ Panels } & \multicolumn{8}{|c|}{ Logarithm of reduction factor at frequency bands ${ }^{1-}$} \\
\hline & $\begin{array}{l}250-257 \\
\text { cy./sec. }\end{array}$ & $\begin{array}{c}1,000- \\
1,087 \\
\mathrm{cy} / \mathrm{sec} .\end{array}$ & $\begin{array}{c}2,000- \\
2,570 \\
\mathrm{cy} . / \mathrm{sec} .\end{array}$ & $\begin{array}{c}3,000- \\
3,470 \\
\mathrm{cy} \cdot / \mathrm{sec}\end{array}$ & $\begin{array}{l}250-257 \\
\text { cy./sec. }\end{array}$ & $\begin{array}{c}1,000- \\
1,087 \\
\text { cy./sec. }\end{array}$ & $\begin{array}{c}2,000- \\
2,570 \\
\mathrm{cy} . / \mathrm{sec} .\end{array}$ & $\begin{array}{c}3,000- \\
3,470 \\
\text { cy./sec. }\end{array}$ \\
\hline $\begin{array}{l}7 \ldots \\
9 \\
15\end{array}$ & $\begin{array}{l}5.72 \\
6.29 \\
5.87\end{array}$ & $\begin{array}{l}6.04 \\
6.32 \\
6.13\end{array}$ & $\begin{array}{l}6.84 \\
7.47 \\
6.16\end{array}$ & $\begin{array}{l}6.83 \\
7.33 \\
5.97\end{array}$ & $\begin{array}{l}5.83 \\
6.84 \\
6.93\end{array}$ & $\begin{array}{l}5.44 \\
6.06 \\
6.14\end{array}$ & $\begin{array}{l}6.69 \\
7.18 \\
6.54\end{array}$ & $\begin{array}{l}6.92 \\
7.24 \\
6.63\end{array}$ \\
\hline
\end{tabular}

1 Last four columns are measurements taken 18 months later than those of the first four columns. 
A study of these results shows that there is no appreciable change as regards sound transmission of the panels after the first three months.

\section{GENERAL SPECIFICATIONS FOR CONSTRUCTION OF TEST PANELS}

\section{ERECTION OF WOOD STUDS}

Three pieces $17 / 8$ by $33 / 4$ inches, each 7 feet $11 / 2$ inches long, were cut and placed in the frame parallel to each other and 17 inches on centers in such a way as to divide the frame into four compartments, each 7 feet $1 / 2$ inch long by 15 inches wide by $33 / 4$ inches deep. Each piece was securely toenailed to the top and bottom members of the frame.

\section{ERECTION OF BRICK WALL}

This was built in an iron frame of 5 -inch channel iron. The brickwork was 4 inches thick, of medium-burned clay, and was laid in a mortar composed of 1 part Portland cement, 1 part mason's hydrated lime, and 6 parts sand by volume. The surfaces to be plastered were reasonably true and free from dirt or loose material. The joints were flush with the surface.

\section{ERECTION OF GYPSUM TILE}

Tile 3 by 12 by 30 inches, with circular cores lengthwise, were used. They were laid in a mortar composed of 1 part retarded, unfibered, neat gypsum plaster to 2 parts of sand, by weight, to form a 3 -inch wall. The surfaces to be plastered were reasonably true and free from dirt or loose material. The joints were flush with the surfaces.

\section{LIME BROWN COAT ON MASONRY}

This coat was composed of one bag of mason's hydrated lime and $2 \frac{1}{2}$ cubic feet of dry sand. The two ingredients were thoroughly mixed, first dry and again wet. The plaster was applied to the wall with sufficient pressure to form a good bond, and was rodded, darbied, and floated to a true and even surface. Both sides of the panel were plastered. The thickness of this scratch coat was such that the least distance from the exposed surface of the plaster to the nearer surface of the masonry was five-eighths inch.

\section{GYPSUM BROWN COAT ON MASONRY}

This coat was composed of one bag of retarded neat gypsum plaster and $1 \frac{1}{2}$ cubic feet of dry sand. The ingredients were thoroughly mixed, first dry and again wet. The plaster was applied to the wall with sufficient pressure to form a good bond and was 
rodded, darbied, and floated to a true and even surface. The thickness of this scratch coat was such that the least distance from the exposed surface of the plaster to the nearer surface of the masonry was five-eighths inch.

\section{SMOOTH WHITE FINISH COAT}

This coat was composed of one bag of finishing hydrated lime to one-half bag of unretarded gypsum gauging plaster. The lime was made into a putty with water at least 24 hours prior to use and stored under a damp cloth. A small amount of this putty was circled out on the plasterer's board, some water was put into the circle, and gauging plaster equal to one-half the volume of the putty was dusted into the water. The whole was then mixed with a trowel, more water being added if necessary. More material was not mixed at one time than could be used in 30 minutes. The mixture was not retempered, but each batch was started with clean board and tools. This plaster was a thin, even layer over the brown coat. It was watched carefully for the appearance of incipient crystallization. When this occurred it was immediately troweled down to a smooth, true finish, using considerable pressure on the trowel, and brushing the surface with water if necessary. This coat was as thin as possible without permitting the brown coat to show through.

\section{ERECTION OF METAL STUDS}

The metal studs were lengths of three-fourths-inch steel channels. They were cut 7 feet 2 inches long and sprung into holes drilled in the top and bottom members of the frame. These holes were of such depth that the studs fitted tightly, but were not noticeably bowed. The studs were spaced 17 inches on centers, and the common center line of the studs was midway between the two faces of the panel. The bottom of the channel was parallel to the faces of the panel.

\section{ERECTION OF SOLID PARTITIONS}

The metal studs were erected as described in paragraph 7. One layer of metal lath was attached to the bottoms of the channels, as specified in paragraph 11 . The scratch coat was applied to that surface of the lath which was fully exposed, as specified in paragraph 9. Before this scratch coat had set another scratch coat was applied to the opposite side of the same lath, in between the studs. After the two scratch coats had been scratched and become reasonably hard, the two brown coats were applied as specified in paragraph 10 , except that the two were of different thicknesses. The thickness from the exposed surface of the finished brown coat to the nearer face of the studs was five-eighths inch on both sides of the panel. The finish coats were applied to both sides as specified in paragraph 6 . 


\section{SCRATCH COAT, GYPSUM PLASTER, ON LATH}

This coat was composed of one bag of retarded neat fibered gypsum plaster, $1 \frac{1}{2}$ cubic feet of sand. The ingredients were thoroughly mixed, first dry and again wet, and applied to the lath with sufficient pressure to force the plaster in between the laths to form a good key. The exposed surface was reasonably true and covered the face of the lath about one-fourth inch. When nearly hard the surface of the coat was scratched with an appropriate tool, making scratches about $1 \frac{1}{2}$ inches apart. It was allowed to set until it took considerable pressure to break down the edges of the scratches when rubbed with the thumb.

\section{BROWN COAT, GYPSUM PLASTER, ON LATH}

This coat was composed of one bag of retarded neat fibered gypsum plaster to $2 \frac{1}{2}$ cubic feet of sand. The ingredients were thoroughly mixed, first dry and again wet, and applied to the scratch coat with sufficient pressure to force the plaster into the scratches. This coat was built out until the total thickness from the face of the studs to the face of the plaster was seven-eighths inch, rodded, darbied, and floated to a true, even surface. It was allowed to set until practically air dry.

\section{ERECTION OF METAL LATH}

This was expanded metal lath, painted, medium weight (3.0 lbs./yd. $\left.{ }^{2}\right)$. The sheets were attached to both sides of the panel, with their longer dimensions across the supports. A sheet of lath being 8 feet long, there were no joints between ends of sheets. The joints between sides of sheets were lapped a full mesh and tied with No. 18 iron wire once, midway between each two supports. Each sheet was securely fastened to every support it crossed, the fastenings being spaced 6 inches apart across the width of the sheet.

\section{ERECTION OF GYPSUM WALL BOARD}

These boards were 48 by 72 by $3 / 8$ inches. Unless otherwise specified, both sides of the panel were covered with these boards. The boards were attached by nails, spaces 6 to 8 inches. All joints were made on the studding, and these joints were pointed up with gypsum wall board filler.

\section{ERECTION OF ASBESTOS BOARD AND CELOTEX}

These materials were erected in accordance with the manufacturers' directions. 


\section{DESCRIPTION OF PANELS}

25. Brick panel, brown coat of lime plaster, smooth white finish.

26. Brick panel, brown coat of gypsum plaster, smooth white finish.

29. Gypsum tile, brown coat of lime plaster, smooth white finish.

30a. Gypsum tile, brown coat of gypsum plaster, smooth white finish. Plastered on one side only.

$30 \mathrm{~b}$. Gypsum tile, brown coat of gypsum plaster, smooth white finish. Plastered on both sides.

30c. Gypsum tile. This was constructed of panels similar to panel

No. 30a placed parallel to each other and separated by a $1 \frac{1}{2}$-inch air space, the plastered surfaces outside. The only mechanical bond between the two parts was the common support around the edges.

50. Wood studs, Sheetrock on both sides of studs, joints filled.

51. Wood studs, Gypsolite on both sides of studs, joints filled.

52. Wood studs, one-half inch asbestos "hard" millboard on one side of studs only, joints filled.

55. Wood studs, one-half inch Celotex on one side of studs only.

56. Wood studs. On one side of the wood studs there was placed a layer of Celotex, then a layer of hair felt, and finally a second layer of one-half inch Celotex. This was all nailed to the studs as loosely as possible.

57. Wood studs, Sheetrock on one side of the studs only.

58. Wood studs. On one side of the wood studs was placed a layer of Sheetrock, then a 1-inch layer of hair felt, and finally a second layer of Sheetrock. This was all nailed to the studs as loosely as possible.

59. Two-inch solid back-plastered partition, metal studs, metal lath.

59a. This panel consisted of two panels similar to No. 59, placed in the horizontal opening of the sound chamber and held apart at the corners with 2 -inch wooden blocks.

59b. Same as No. 59a, except the wooden blocks were made thinner and a pad of 1-inch hair felt placed above and below each block, the air space between the panels remaining 2 inches.

59c. Same as No. 59b, except that a layer of 1 -inch hair felt was slipped into the air space between the panels.

$59 \mathrm{~d}$. Same as $59 \mathrm{~b}$, except that a layer of single ply Cabots Quilt was slipped into the air space between the panels.

59e. Same as 59b, except a layer of one-half inch Celotex was slipped into the air space between the panels.

Washington, March 24, 1927. 


